\title{
PERBANDINGAN HASIL BELAJAR SISWA PADA MATERI BRYOPHYTA MENGGUNAKAN MODEL PEMBELAJARAN INKUIRI DENGAN KOOPERATIF GROUP INVESTIGATION (GI) DI SMA KELAS X
}

\author{
Devi Lestari \\ Universitas Palangka Raya \\ e-mail: devilestari@gmail.com
}

\begin{abstract}
Abstrak
Penelitian ini bertujuan mengetahui perbedaan hasil belajar siswa pada materi Bryophyta menggunakan model pembelajaran inkuiri dengan kooperatif Gl. Hasil belajar afektif siswa, keterampilan siswa belajar dan proses pelaksanaan model pembelajaran. Metode penelitian yang digunakan adalah quasi experiment dengan desain nonequivalent control group design. Sampel penelitian adalah siswa kelas X-2 dan X-4 SMAN-6 Palangka Raya. Pengumpulan data menggunakan soal tes yang sudah valid. Pengujian hipotesis menggunakan uji-t. Hasil dari penelitian diperoleh nilai p0,01< 0,05 . Maka kesimpulan bahwa terdapat perbedaan yang signifikan antara hasil belajar siswa menggunakan model pembelajaran inkuiri dengan kooperatif Gl. Aspek kognitif melalui pembelajaran inkuiri untuk aspek C2 dikatakan baik, sedangkan aspek kognitif melalui kooperatif Gl untuk aspek C1, C2, dan C3 dikatakan sangat baik. Hasil afektif siswa yang belajar melalui model pembelajaran inkuiri dan kooperatif Gl diperoleh nilai yang sangat baik untuk aspek jujur. Hasil keterampilan siswa belajar melalui model pembelajaran kooperatif GI sangat baik dibanding model pembelajaran inkuiri. Hasil proses pelaksanaan model melalui pembelajaran inkuiri dan model pembelajaran kooperatif Gl terlaksana dengan baik.
\end{abstract}

Kata kunci: Hasil Belajar, Pembelajaran Inkuiri, Pembelajaran Kooperatif GI

\begin{abstract}
This study aimed to describe the differences of the students' learning outcomes in Bryophyta material by using the model of inquiry learning and Gl cooperative learning in the aspect of affective results of students learning, students' learning skills and the process of implementing learning models. The research method used is quasi experimental with nonequivalent control group design. The research sample is the students of X-2 and X-4 in SMAN-6 Palangka Raya. The data collected with valid test questions and hipotized by using t-test. The results of the study obtained $\mathrm{p} 0,01<\alpha 0,05$. This result proved the significant differences between students' learning outcomes by using the model of inquiry learning and $\mathrm{Gl}$ cooperative learning. Cognitive aspects through inquiry learning for the $\mathrm{C} 2$ are into good chategory while cognitive aspects through $\mathrm{Gl}$ cooperation for aspects of $\mathrm{C} 1$, $\mathrm{C} 2$, and $\mathrm{C} 3$ are in excellent chategory. The affective result on learning, in terms of honesty is chategorized excellent. The results of students' learning skills through Gl cooperative learning models are more significant compared to inquiry learning models. The results of the model implementation process through inquiry learning and cooperative learning models $\mathrm{Gl}$ are well implemented.
\end{abstract}

Keywords: Learning Outcomes, Inquiry Learning, GI Clearning 


\section{PENDAHULUAN}

Hasil belajar merupakan hasil akhir dari proses kegiatan belajar siswa dalam mengikuti pembelajaran di kelas untuk mencapai tujuan pembelajaran berupa aspek kognitif yang menggunakan alat penilaian yaitu tes evaluasi dengan hasil yang dinyatakan dalam bentuk nilai, aspek afektif yang menunjukkan sikap siswa dalam mengikuti pembelajaran, dan aspek psikomotorik yang menunjukkan keterampilan dan kemampuan bertindak siswa dalam mengikuti pembelajaran. Hasil belajar ditandai dengan perubahan tingkah laku, walaupun tidak semua perubahan tingkah laku merupakan hasil belajar, akan tetapi aktivitas belajar umumnya disertai perubahan tingkah laku. Perubahan hasil belajar juga ditandai dengan aspek kognitif kemampuan berpikir siswa. Untuk mendukung perubahan hasil belajar guru dituntut mampu mengembangkan model-model pembelajaran melalui praktek pengamatan langsung ataupun pemecahan masalah, karena model pembelajaran yang dikembangkan diharapkan mampu memberikan petunjuk atau arahan bertujuan menekankan keaktifan berpikir siswa untuk mendorong perubahan kemampuan berpikir siswa.

Sekolah menengah atas negeri 6 Palangka Raya merupakan sekolah yang terletak dipinggir Kota Palangka Raya, Kalimantan Tengah. Berdasarkan hasil wawancara dengan guru Biologi diperoleh informasi, dalam proses pembelajaran biologi khususnya materi Bryophyta, ditemukan beberapa masalah, untuk mengajar guru hanya memberi informasi menggunakan buku paket biologi, hanya mengguna metode ceramah, tidak adanya pengguna media pembelajaran. Hal tersebut mengakibatkan kurangnya siswa minat belajar, tidak konsentrasi dalam proses pembelajaran, dan berpengaruh pada hasil belajar siswa yang rendah bahkan ada tidak memenuhi nilai ketuntasan. Berdasarkan hasil wawancara dengan siswa diperoleh informasi, bahwa mereka mengalami kesulitan memahami materi Bryophyta pada pengelompokkan dan metagenesis Bryophyta, kurangnya pengalaman dan kemampuan praktel melakukan pengamatan secara langsung, serta siswa banyak tidak mengetahui jenis-jenis dari Bryophyta yang hidup di lingkungan sekitar. Berdasarkan hasil dari tes pendahuluan yang dilakukan peneliti, diperoleh hasil belajar siswa belum tercapai sesuai tujuan pelajaran yang diharapkan, terutama dalam aspek kognitif ada banyak siswa yang tidak tuntas.

Pada materi Bryophyta berdasarkan tuntutan kompetensi dasar, siswa dituntut mampu mendeskripsikan dan menjelaskan tentang Bryophyta. Kemampuan untuk mendeskripsikan tentang Bryophyta, siswa harus melakukan suatu praktek pengamatan langsung. Dari pengamatan yang dilakukan menghasilkan suatu data diolah dan dimaknai oleh siswa sehingga memperoleh kesimpulan. Dengan kegiatan demikian siswa mampu mendeskripsikan dan menjelaskan tentang Bryophyta dengan baik dan proses pembelajaran sesuai dengan kebutuhan belajar siswa. 
Untuk mendukung kebutuhan kegiatan belajar siswa maka diperlukan instrumen pembelajaran yang menggunakan model-model pembelajaran yang dapat memfasilitasi dan mengarahkan kegiatan siswa. Model pembelajaran tersebut di antaranya yaitu dan kooperatif group investigation. Model pembelajaran inkuiri merupakan strategi terpusat pada siswa. Siswa belajar secara berkelompok dan akan diarahkan pada suatu masalah dan mencari jawaban atas masalah tersebut dengan prosedur yang jelas. hal ini dukung dengan penelitian yang telah dilakukan oleh Seniwati (2015) mengenai penerapan model pembelajaran inkuiri terhadap hasil belajar, sikap dan aktivitas siswa. Hasil penelitian menunjukkan terdapat peningkatan hasil belajar siswa dan prestasi siswa, serta aktivitas siswa. Selanjutnya penelitian oleh Mustachfidoh (2013) mengenai pengaruh model pembelajaran inkuri terhadap prestasi ditinjau dari inteligensi. Hasil penelitian diperoleh terdapat perbedaan prestasi belajar biologi yang signifikan antara kelompok siswa yang belajar dengan model pembelajaran inkuiri dan model pembelajaran langsung dengan inteligensi kelompok atas maupun kelompok atas, kemudiam hasil uji lanjut menunjukkan bahwa model pembelajaran inkuiri lebih unggul dibandingkan dengan model pembelajaran langsung terhadap prestasi belajar biologi.

Model pembelajaran kooperatif group investigation merupakan pembelajaran menekankan pada partisipasi dan aktivitas siswa untuk mencari sendiri informasi pelajaran yang akan dipelajari melalui bahan-bahan yang tersedia, misalnya dari buku pelajaran atau siswa dapat mencari melalui internet. Siswa dilibatkan dalam perencanaan hingga cara untuk mempelajarinya melalui investigasi penyelidikan. Model pembelajaran ini menuntut siswa untuk memiliki kemampuan yang baik dalam berkomunikasi dan keterampilan berkelompok, sehingga melatih siswa untuk menumbuhkan kemampuan berpikir dan sosialisasi. Keterlibatan siswa secara aktif mulai dari tahap pertama sampai tahap akhir kegiatan pembelajaran. Hal ini didukung dari penelitian yang telah dilakukan oleh Artini, Pasaribu, \& Husain (2015), mengenai penerapan model pembelajaran kooperatif group investigation terhadap hasil belajar dan aktivitas siswa. Hasil penelitian menunjukkan bahwa penggunaan model pembelajaran group investigation meningkatkan hasil belajar kognitif, afektif dan psikomotor, serta aktivitas guru dan siswa. Kemudian penelitian oleh Trismanita, Tri, \& Rini (2014), bahwa hasil penelitian menunjukkan aktivitas belajar siswa mengalami peningkatan dan juga hasil belajar siswa.

\section{METODE}

Jenis penelitian yang digunakan quasi experiment dengan desain nonequivalent control group design. Desain penelitian dapat dilihat pada Tabel 1. 
Tabel 1. Desain penelitian

\begin{tabular}{lcll}
\hline Kelompok & Pretest & Perlakuan & Postest \\
\hline Eksperimen 1 & $\mathrm{O}_{1}$ & $\mathrm{X}_{1}$ & $\mathrm{O}_{3}$ \\
Eksperimen 2 & $\mathrm{O}_{2}$ & $\mathrm{X}_{2}$ & $\mathrm{O}_{4}$ \\
\hline
\end{tabular}

Prosedur pengumpulan data mengunakan instrumen sebagai berikut: (1) Hasil belajar kognitif siswa menggunakan soal tes yang sudah divalid berupa pilihan ganda 30 butir soal; (2) Penilaian afektif siswa menggunakan lembar observasi yang dinilai oleh pengamat; (3) Penilaian keterampilan siswa belajar menggunakan lembar penilaian yang dilakukan oleh guru; (4) Penilaian proses pelaksanaan model pembelajaran inkuiri dan kooperatif Gl menggunakan lembar observasi yang dinilai oleh pengamat. Hasil kognitif siswa kemudian dianalisis menggunakan uji-t melalui sistem statistical package for social sciense (SPSS) versi 23. Meliputi uji normalitas, uji homogenitas, dan uji-t dengan taraf signifikansi $\alpha 0,05$.

Hasil analisis afektif siswa belajar dikategorikan seperti di Tabel 2.

Tabel 2. Pengkategorian Afektif Siswa

\begin{tabular}{cc}
\hline Interval & Kategori \\
\hline $80-100$ & Sangat baik \\
$66-79$ & Baik \\
$56-65$ & Cukup \\
$\leq 55$ & Kurang \\
\hline
\end{tabular}

Arikunto, 2012

Hasil analisis keterampilan siswa dan keterlaksanaan model pembelajaran dikategorikan seperti di Tabel 3.

Tabel 3. Pengkategorian Keterampilan Siswa

\begin{tabular}{ll}
\hline Interval & Kategori \\
\hline $85-100$ & Sangat baik \\
$70-84$ & Baik \\
$55-69$ & Cukup \\
$\leq 54$ & Kurang \\
\hline
\end{tabular}

\section{HASIL DAN PEMBAHASAN}

Hasil aspek kognitif melalui model pembelajaran inkuiri dan model pembelajaran kooperatif GI diperlihatkan pada Gambar 1 berikut: 


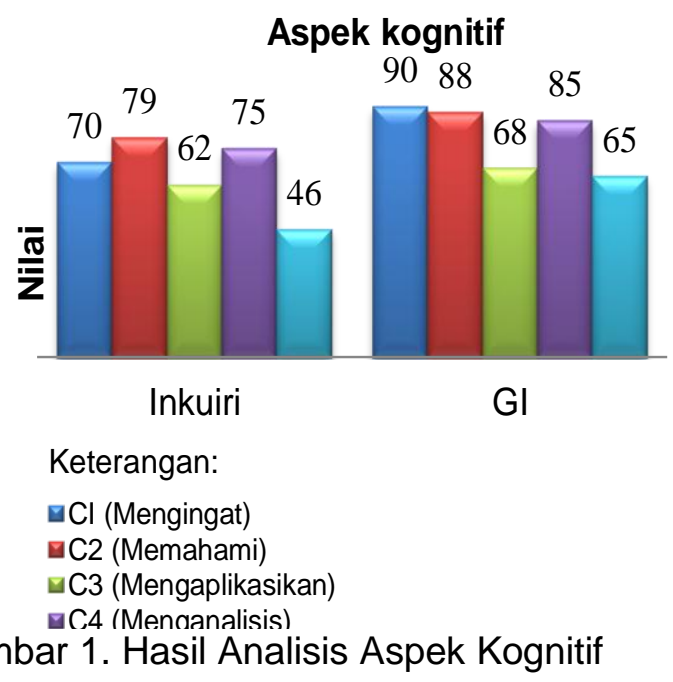

Hasil analisis aspek kognitif melalui model pembelajaran inkuiri diperoleh nilai yang tinggi yaitu aspek C2 (memahami) sebesar 79 sehingga dikategorikan baik, hal ini menunjukkan siswa dapat memahami tentang materi pelajaran yang telah dipelajari dan dapat memanfaatkannya tanpa harus menghubungkannya dengan hal-hal lain. Aspek kognitif yang rendah perolehan nilainya yaitu aspek C5 (evaluasi) sebesar 46 dikategorikan kurang, hal ini dikarenakan siswa kurang mampu mengembangkan kemampuan untuk mengevaluasi suatu pernyataan atau konsep berdasarkan kriteria tertentu. Hasil analisis aspek kognitif melalui model pembelajaran kooperatif Gl diperoleh nilai yang tinggi yaitu aspek C1 (mengingat) sebesar 90, aspek C2 (memahami) sebesar 88, dan C4 (menganalisis) sebesar 85 sehingga dikategorikan sangat baik, hal ini menunjukkan siswa dapat mengetahui, memahami, dan menganalisi suatu pernyataan atau konsep ke dalam unsur-unsur atau komponen pembentuknya.

Berdasarkan hasil pengujian hipotesis ditemukan bahwa terdapat perbedaan signifikan antara hasil belajar siswa yang belajar melalui model pembelajaran inkuiri dengan model pembelajaran kooperatif Gl. Hasil pengujian hipotesis menggunakan uji-t diperoleh $p 0,01<\alpha 0,05$. Perbedaan hasil belajar siswa terjadi karena model pembelajaran kooperatif GI mampu mendukung siswa belajar materi biologi tentang Bryophyta dengan baik. Model pembelajaran kooperatif GI dapat memfasilitasi kegiatan belajar siswa dalam mempelajari materi pembelajaran Biologi mengenai Bryophyta, karena siswa diberi kebebasan menentukan sendiri sesuai minatnya mengenai subtopik yang dipelajari secara berkelompok. Siswa kemudian membuat rencana kegiatan untuk melakukan kegiatan penyelidikan sesuai dengan subtopik yang telah dipilih secara berkelompok, hal ini perlu dilakukan agar siswa mengetahui apa yang dipelajari, bagaimana mempelajari dan membagi tugas anggota kelompok. Berkerjasama di dalam kelompok untuk melakukan penyelidikan melalui pengamatan dan investigasi dari berbagasi sumber belajar yang 
relevan, dan membuat laporan investigasi, hal ini dilakukan agar siswa mengumpulkan informasi yang benar tidak keliru mengenai subtopik yang dipelajari, dan melatih siswa berdiskusi untuk menggabungkan semua informasi dari anggota kelompok. Hasil penelitian yang relevan telah dilakukan oleh Artini, Pasaribu, \& Husain (2015) bahwa penggunaan model pembelajaran group investigation meningkatkan hasil belajar kognitif siswa. Hal yang sama juga temukan juga oleh Trismanita, Tri, \& Rini (2014) bahwa penerapan model pembelajaran group investigation berpengaruh terhadap peningkatan hasil belajar siswa.

Deskripsi hasil belajar afektif melalui model pembelajaran inkuiri dan kooperatif GI.

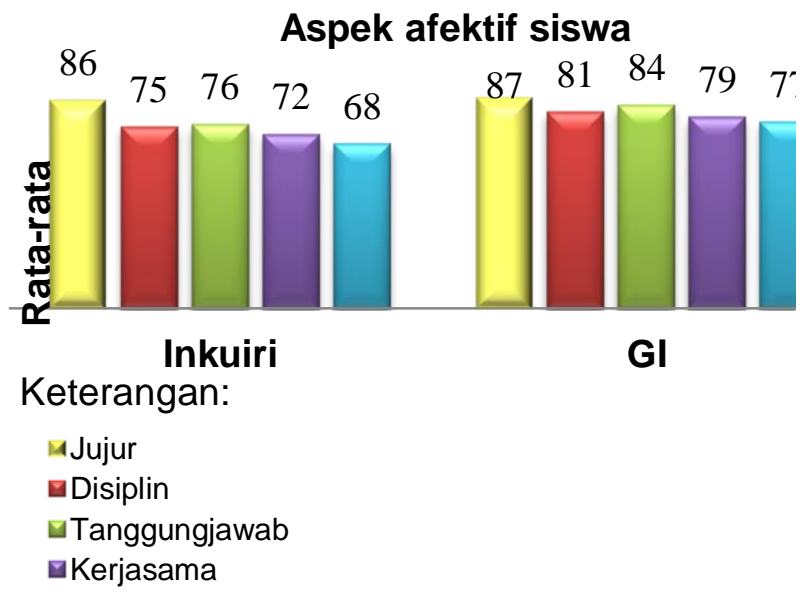

Gambar 2. Hasil Belajar Afektif Melalui Model Pembelajaran Inkuiri dan Kooperatif GI

Hasil afektif siswa yang belajar melalui model pembelajaran inkuiri dan model pembelajaran kooperatif Gl diperoleh nilai yang sangat baik pada aspek jujur, karena deskriptor penilaian aspek jujur semua tampak, yaitu membuat rangkuman secara obyektif terhadap data yang dihasilkan, melakukan kegiatan sesuai prosedur secara objektif, melakukan kegiatan pengamatan sesuai dengan langkah-langkah pada lembar kerja siswa, dan mencatat data sesuai dengan hasil pengamatan.

Hasil afektif siswa yang belajar melalui model pembelajaran inkuiri diperoleh aspek disiplin, tanggungjawab, kerjasama, dan responsif nilai rerata lebih rendah dibanding hasil afektif siswa yang belajar melalui model pembelajaran kooperatif GI. Hal ini terjadi karena hanya beberapa deskriptor penilaian saja yang tampak, yaitu yaitu bersedia untuk mewakili kelompok dalam melakukan observasi atau pengamatan, dan menyelesaikan tugas tetapi tidak memberi ide atau solusi dengan benar. Perbedaan afektif siswa yang belajar melalui model pembelajaran inkuiri terjadi karena siswa kesulitan merespons dalam pembelajaran disebab kebiasaan siswa dalam belajar yang terpaku dengan buku, sehingga kurang mendorong movitasi siswa belajar. Hal sejalan dengan Trianto (2008) dalam implementasi model pembelajaran inkuiri akan mengalami kendala dalam merencanakan pembelajaran oleh karena terbentur dengan kebiasaan siswa dalam belajar dan siswa yang memiliki 
kemampuan rendah akan mengalami kesulitan dalam belajar, serta jumlah siswa yang relatif banyak membuat tidak terkelola dengan baik.

Hasil afektif siswa yang belajar menggunakan model pembelajaran kooperatif Gl diperoleh aspek disiplin dan tanggungjawab, dikategorikan sangat baik, sebab siswa dalam proses pembelajaran kooperatif Gl deskriptor aspek penilaian semua tampak, di antaranya yaitu, merangkuman secara obyektif semua data yang dikumpulkan, taat dan patuh terhadap tugas yang dibagi dalam kegiatan berdiskusi kelompok, melaksanakan tugas yang diberikan oleh guru maupun peran yang diberikan dalam kelompok dan menyelesaikan tugas sampai tuntas. Penerapan model pembelajaran kooperatif GI dapat mendorong motivasi belajar siswa, dan membuat suasana menyenangkan, serta belajar saling berkerjasama didalam kelompok. Hal ini sejalan dengan Setiawan (2006), penggunaan model pembelajaran kooperatif Gl yaitu, membuat suasana saling bekerjasama dan berinteraksi antar siswa dalam kelompok tanpa memandang latar belakang, melatih siswa untuk memiliki kemampuan yang baik dalam berkomunikasi dan mengemukakan pendapat, memotivasi siswa agar aktif dalam proses belajar mulai dari tahap awal sampai tahap akhir pembelajaran.

Hasil keterampilan siswa belajar melalui model pembelajaran inkuiri dan kooperatif Gl diperlihatkan pada Gambar 3.

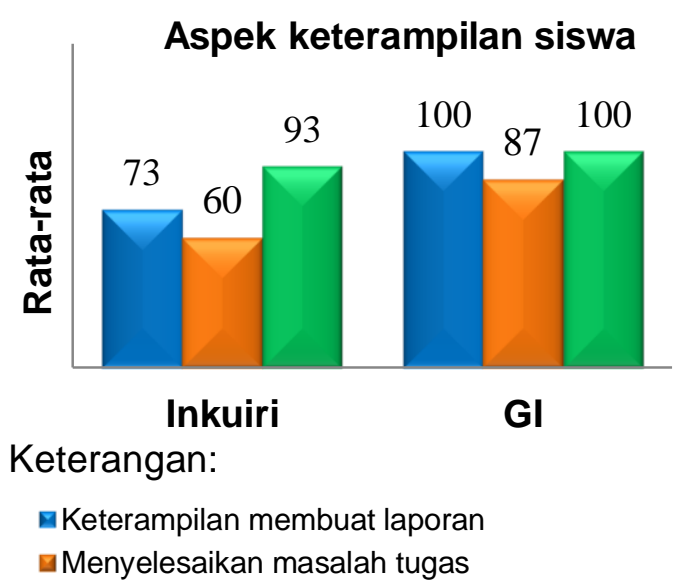

Gambar 3. Hasil Belajar Keterampilan Siswa Melalui Model Pembelajaran Inkuiri dan Kooperatif GI

Hasil keterampilan siswa yang belajar melalui model pembelajaran inkuiri dan kooperatif GI, berdasarkan hasil analisis model pembelajaran kooperatif GI sangat baik dibandingkan model pembelajaran inkuiri. Hasil ini dikarenakan siswa kelompok belajar melalui model pembelajaran kooperatif GI terampil membuat laporan, mampu menyelesaikan tugas dalam memecahkan masalah dengan benar, dan dapat mengkomunikasikasi laporan secara terampil saat presentasi di kelas. Keterampilan siswa yang belajar melalui model pembelajaran inkuiri hanya dikategorikan baik, dibanding model pembelajaran kooperatif GI pada kategori sangat baik, dikarenakan siswa tidak terbiasa 
belajar mandiri, sering mengumpulkan informasi yang kurang relevan pembelajaran inkuiri dan menghasilkan informasi yang kurang lengkap atau keliru, sehingga menyelesikan tugas dalam memecahkan masalah dengan tidak benar. Oleh karena itu menyebabkan turunnya kepercayaan diri dalam mengkomunikasikan laporan. Di dalam hasil temuan oleh Seniwati (2015), bahwa model pembelajaran inkuiri meningkatkan aktivitas siswa belajar. Perbedaan hasil temuan terjadi karena model pembelajaran inkuiri sulit terapkan pada siswa yang mempunyai kemampuan merespons dan motivasi belajar yang kurang. Hal ini sejalan dengan Sanjaya (2006) pembelajaran inkuiri akan kurang berhasil jika diterapkan kepada siswa memiliki kemauan untuk berpikir yang kurang. Deskripsi proses pelaksanaan model pembelajaran inkuiri dan kooperatif Gl.

\section{Langkah Pembelajaran Inkuiri}

100100100100100100100

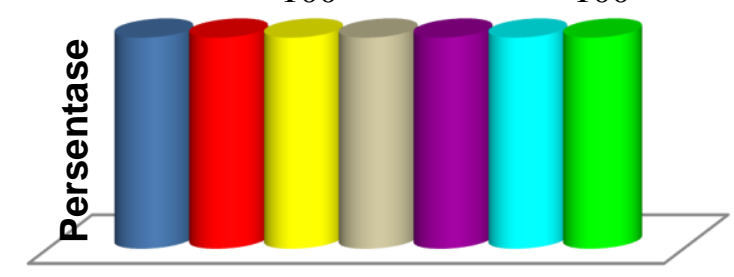

Keterangan: Inkuiri

1. Orientasi

-2. Merumuskan masalah

3. Mengajukan Hipotesis

- 4 . Menggumpukan data

-5. Menguji hipotesis

6. Merımı ıskan kesimnılan

Gambar 4. Hasil Proses Pelaksanaan Pembelajaran Inkuiri

Proses pelaksanaan model pembelajaran inkuiri terlaksana mencapai 100\%, artinya terlaksana dengan baik. Langkah pembelajaran inkuiri ada 7, yaitu orientasi, pada langkah ini guru menjelaskan topik pembelajaran, tujuan pembelajaran yang dicapai oleh siswa setelah proses pembelajaran. Guru memotivasi siswa dengan media berupa batu yang ditumbuhi oleh tumbuhan lumut, selanjutnya memberikan pertanyaan dan siswa merespons pertanyaan tersebut. Langkah merumuskan masalah, guru meminta siswa sebelum merumuskan masalah, guru memberi kesempatan untuk siswa membaca bahan ajar yang tersedia, sebagai dasar siswa membuat rumusan masalah. Guru kemudian mengajukan pertanyaan kepada siswa untuk membuat rumusan masalah mengenai tumbuhan lumut. Langkah mengajukan hipotesis, siswa membuat hipotesis atau jawaban sementara terhadap pertanyaan rumusan masalah yang telah diajukan mengenai tumbuhan lumut. Langkah mengumpulkan data, siswa mengumpulkan data melalui pengamatan langsung, diberikan kesempatan bagi siswa untuk keluar kelas untuk mencari tumbuhan lumut di sekitar lingkungan sekolah. Siswa selanjutnya menggumpulkan data informasi mengenai jenis lumut yang tidak ditemuinya di lingkungan sekolah dengan membaca bahan ajar. Langkah menguji hipotesis, siswa melakukan diskusi untuk 
menentukan jawaban yang paling tepat berdasarkan data yang diperoleh dari pengumpulan data berhubungan dengan rumusan masalah yang diajukan. Guru membimbing siswa berdiskusi menguji hipotesis. Langkah merumuskan kesimpulan, siswa membuat kesimpulan hasil kinerja yang dilakukan secara bersama dalam kelompok mengenai tumbuhan lumut. Langkah terakhir yaitu mengkomunikasi, siswa mempresentasi hasil kinerja, kemudian melakukan diskusi kelas mengenai tumbuhan lumut, hal penting agar siswa terampil dalam berkomunikasi mengajukan pertanyaan atau tanggapan.

\section{Langkah pembelajaran kooperatif GI}

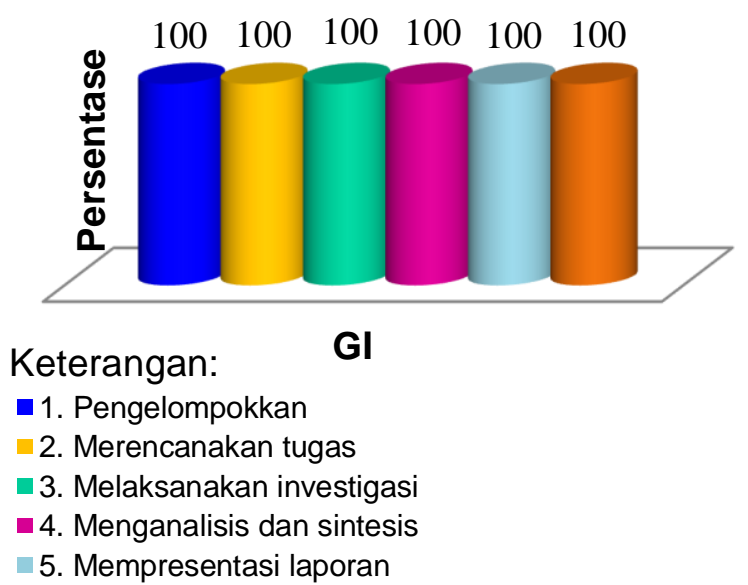

Gambar 5. Hasil Proses Pelaksanaan Model Pembelajaran Kooperatif GI

Proses pelaksanaan model pembelajaran kooperatif GI terlaksana mencapai 100\%, artinya terlaksana dengan baik. Langkah pembelajaran inkuiri ada 6, langkah pengelompokan, guru memberikan gambaran mengenai topik dan subtopik investigasi yang dipelajari yaitu Bryophyta. Siswa yang tertarik terhadap subtopik sama, kemudian membentuk kelompok. Langkah merencanakan tugas (planning), siswa membuat perencanaan tugas-tugas apa saja yang perlukan dilakukan untuk mempelajari subtopik mengenai Bryophyta. langkah melaksanakan investigasi, siswa diberi kesempatan untuk mengamati tumbuhan lumut secara langsung, kemudian melakukan investigasi, baik dari buku yang relevan maupun dari internet. Langkah analisis dan sintesis, siswa berdiskusi di kelompok masing-masing untuk menentukan informasi paling tepat hasil investigasinya dan menggabungkan informasi-informasi yang diperolah anggota kelompok. Siswa kemudian membuat laporan hasil investigasi dan membentuk seperti panitia untuk mempresentasikanlaporan mempresentasikan laporan akhir, siswa mempresentasi laporan hasil investigasi, dan kelompok siswa yang sebagai pendengar bertugas memberikan pertanyaan. Guru memfasilitasi siswa melakukan kegiatan diskusi kelas. Langkah terakhir yaitu, evaluasi, siswa bersama menggabungkan semua informasi yang diperoleh setiap kelompok mengenai tumbuhan lumut, selanjutnya bersama dengan membuat kesimpulan mengenai topik pelajaran tentang tumbuhan lumut. 


\section{SIMPULAN}

Berdasarkan hasil penelitian, maka disimpulkan bahwa terdapat perbedaan hasil belajar siswa menggunakan model pembelajaran inkuiri dengan kooperatif GI. Ditemukan hasil bahwa model pembelajaran kooperatif GI mampu mendukung kebutuhan siswa belajar materi biologi tentang Bryophyta sehingga berpengaruh meningkatkan hasil belajar dari aspek kognitif, afektif dan psikomotorik. Maka dari itu disaran apabila Guru membuat rancangan pembelajaran menggunakan model pembelajaran kooperatif $\mathrm{Gl}$, dengan memperhatikan aktivitas siswa memilih topik pelajaran sesuai minat, pembentukan kelompok berdasarkan topik yang dipilih, kemampuan siswa bekerja mencari informasi secara mandiri dalam kelompok.

\section{DAFTAR PUSTAKA}

Arikunto, S. 2012. Dasar-Dasar Evaluasi Pendidikan. Jakarta: Bumi Aksara.

Artini, Pasaribu, M,.\& Husain, S. 2015. Penerapan model pembelajaran kooperatif tipe group investigation untuk meningkatkan aktivitas dan hasil belajar IPA pada siswa kelas VI SD INPRES 1 TONDO. Jurnal Mitra Sains, 3 (1): 45-52.

Mustachfidoh. 2013. Pengaruh model pembelajaran inkuiri terhadap prestasi belajar biologi ditinjau dari inteligensi siswa SMA negeri 1 SRONO. Jurnal Program Pascasarjana Universitas Pendidikan Ganesha, Program Studi Pendidikan Sains, 3(1).

Patricia, P. 2014. Peningkatan keterampilan belajar pada pembelajaran tematik melalui permainan kotak misteri siswa. Jurnal Mitra Sains, 3 (1): 21-35.

Setiawan. 2006.Rancangan Model- Model Pembelajaran. Jakarta : PT Rineka Cipta

Seniwati. 2015. Peningkatan aktivitas, sikap dan hasil belajar biologi melalui penerapan model pembelajaran inkuiri. Jurnal Nalar Pendididkan, 3(1): 317-321.

Trianto. 2008. Model-model pembelajaran inovatif berorientasi konstruktivistik. Bandung: Remaja Rosdakarya.

Trismanita, S, Tri, J \& Rini, R. 2014. Pengaruh penerapan model pembelajaran group investigation terhadap aktivitas dan hasil belajar siswa. Jurnal bioterdidik, 2(1). 